\title{
Human papillomavirus and human cytomegalovirus infection and association with prognosis in patients with primary glioblastoma in Pakistan
}

Syed Adnan Ali

Aga Khan University, syed.adnan@aku.edu

Yumna Mirza

Aga Khan University, yumna.mirza@aku.edu

Zubair Ahmad

Aga Khan University, zubair.ahmad@aku.edu

Nida Zahid

Aga Khan University, nida.zahid@aku.edu

Ather Enam

Aga Khan University, ather.enam@aku.edu

Follow this and additional works at: https://ecommons.aku.edu/pakistan_fhs_mc_surg_surg

Part of the Neurology Commons, Neurosurgery Commons, and the Surgery Commons

\section{Recommended Citation}

Ali, S. A., Mirza, Y., Ahmad, Z., Zahid, N., Enam, A. (2019). Human papillomavirus and human cytomegalovirus infection and association with prognosis in patients with primary glioblastoma in Pakistan. World Neurosurgery, 121( ), e931-e939.

Available at: https://ecommons.aku.edu/pakistan_fhs_mc_surg_surg/760 


\title{
HUMAN PAPILLOMAVIRUS AND HUMAN \\ CYTOMEGALOVIRUS INFECTION AND ASSOCIATION \\ WITH PROGNOSIS IN PRIMARY GLIOBLASTOMA \\ PATIENTS OF PAKISTAN
}

\author{
Syed Muhammad Adnan Ali ${ }^{1 *}$ (Ph.D.), Yumna $\operatorname{Mirza}^{1}$ (Ph. D. fellow), \\ Zubair Ahmad² (FCPS), Nida Zahid ${ }^{1}$ (M.Sc.), Syed Ather Enam³ (Ph.D.)
}

${ }^{1}$ Office of Academia and Research in Surgery, Department of Surgery, Aga Khan University, Karachi, Pakistan

${ }^{2}$ Section of Histopathology, Department of Pathology and Laboratory Medicines, Aga Khan University, Karachi, Pakistan

${ }^{3}$ Section of Neurosurgery, Department of Surgery, Aga Khan University, Karachi, Pakistan

Running Title: HPV and HCMV infection in GBM

Keywords: CNS tumours, infectious oncology, survival, viruses

$\begin{array}{ll}\text { Abbreviations: } \\ \text { BLAST: } & \text { Basic Local Alignment Search Tool } \\ \text { CNS: } & \text { Central nervous system } \\ \text { COX2: } & \text { Cycloxygenase-2 } \\ \text { EGFR: } & \text { Epidermal Growth Factor Receptor } \\ \text { GBM: } & \text { Glioblastoma } \\ \text { HCMV: } & \text { Human cytomegalovirus } \\ \text { HPV: } & \text { Human papillomavirus } \\ \text { IHC: } & \text { Immunohistochemistry } \\ \text { PCR: } & \text { Polymerase chain reaction }\end{array}$

*For correspondence:

Dr. S. M. Adnan Ali

Assistant Professor,

Head of Manuscript and Grants Division,

Office of Academia and Research in Surgery (OARS),

Department of Surgery,

Aga Khan University Hospital,

Stadium Road P.O. Box 3500

Karachi 74800, Pakistan

Email: syed.adnan@aku.edu

Phone: 92-21-34930051 (Ext 4748)

Fax: (92 21) 3493-4294 \& 3493-2095 


\begin{abstract}
Objective: Glioblastoma (GBM) is the most common adult primary brain tumour. Human cytomegalovirus (HCMV) has been studied for the past decade and conflicting results have been reported with no conclusive role has yet been established. Human papillomavirus (HPV) is involved in the pathogenesis of many cancers and has high prevalence in cervical and oral cancer patients of Pakistan. The objective of our study was to identify the prevalence of HCMV and HPV in Pakistani primary GBM patients.
\end{abstract}

Methods: 112 primary GBM biopsies were analyzed. HCMV and HPV infection was investigated using nested and conventional PCR respectively. Positive HPV samples were further confirmed through sequencing. HPV status was correlated with histology and expression of other frequently mutated GBM molecular markers.

Results: Our data had $68 \%$ males and $32 \%$ females. HCMV was detected in only 1 patient while HPV infection was present in $28 \%$ of patients with no cases of HPV and HCMV coinfection. We report for the first time that a majority of HPV positive GBM patients harboured types 16 and 18 both. Among them, 16\% were HPV-type16 and 20\% were HPVtype 18 . HPV infected patients had longer survival times but this was not statistically significant. Most commonly overexpressed molecular marker in HPV positive patients was COX2, and no histological changes were seen in HPV positive GBM cases.

Conclusions: The presence of a single HCMV positive is intriguing. Additionally, we discovered a substantially high $28 \%$ prevalence of HPV in GBM patients. The role of viruses in the gliomagenesis warrants further investigation. 


\section{INTRODUCTION}

Glioblastoma multiforme (GBM), presenting as a common malignant primary brain tumour (WHO grade IV astrocytoma), is the deadliest brain tumour with a poor prognosis and an almost unavoidable tendency of relapse within a short period of time. The average patient survival rate is 14.6 months even after a rigorous multimodal treatment consisting of surgery, chemotherapy and radiotherapy. The 5-year survival rate with maximum available multimodal therapy is a mere $5.5 \% \underline{1,2}$.

GBM has an incidence of 3.2 per 100,000 adults in the US population ${ }^{3}$. In Pakistan, it formed the largest subtype of astrocytic tumours (40.4\%), as was reported in a single-center study of 761 cases of CNS tumours conducted in the years 2009-2013 ${ }^{4}$. The current available treatment constitutes safe surgical resection, radiation therapy and medications including temazolamide (TMZ) and as of latest, avastin, which may marginally improve quality of life but not significantly prolong survival $\stackrel{2,5}{ }$.

Several environmental and genetic factors have been investigated but none has been identified as a risk factor for the larger proportion of GBMs. Cigarette smoking, alcohol use, drug use of any kind or dietary intake of N-nitroso compounds and the use of mobile phones have all been studied and revealed insubstantial evidence of any association with GBM ${ }^{6}$. However, there is growing evidence and consensus for the association of certain viruses with $\mathrm{GBM}^{2}$.

Human cytomegalovirus (HCMV) is a $\beta$-herpes virus infamous for developing encephalitis in-utero and in immunocompromised adults. This double-stranded enveloped DNA virus is complex in its virology with 59 viral proteins and 70 host proteins identified, with mostly

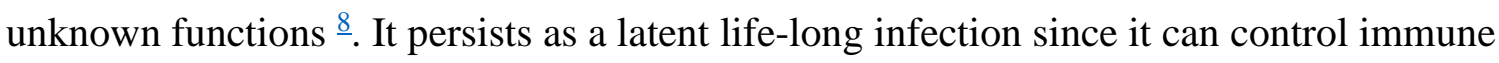
responses effectively, and is asymptomatic at primary infection in healthy adults $\stackrel{9}{\text {. Not }}$ regarded as an oncogenic virus, $\mathrm{HCMV}$ is instead proposed to be an oncomodulator, meaning 
it infects tumour cells and increases their malignancy without direct transformation $\frac{10}{}$. Moreover, it has also shown oncogenic transformation potential in cancers of the breast 11 . The first study to report HCMV in GBM was conducted by Cobbs et al. in $2002 \frac{12}{2}$ and ever since there have been many studies citing presence and others reporting absence of HCMV in glioblastoma $\underline{7,13-18}$.

Along with HCMV, Human papillomavirus (HPV) is also being investigated for any association with high grade gliomas. HPV has over 200 recognized types and belongs to the Papillomaviridae family $\stackrel{19}{ }$. It is an oncogenic virus notably associated with cervical carcinoma as a causative agent and has increasingly become popular in vaginal, penile and

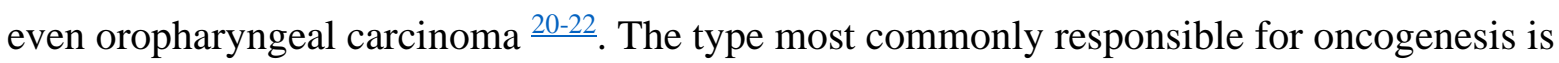
the high-risk type HPV16 and HPV18 while low-risk types like HPV6 are more often linked with benign lesions 19,23 . E6 and E7 are the core genes in HPV, driving the dysregulation of

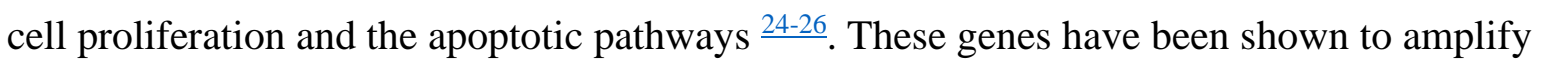
cell proliferation and self-renewal characteristics of neural progenitor cells presumably by breaking down $\mathrm{p} 53$ and $\mathrm{pRb}$ proteins, giving rise to the effects HPV oncogenic proteins may have on the CNS $\stackrel{27}{2}$. So far, only two studies have investigated the presence of HPV in GBM and revealed that a high percentage of GBMs are infected by HPV $\underline{18}$ and this in turn leads to a worse prognosis $\stackrel{28}{\text {. }}$.

The subject of HPV and HCMV co-infection has also garnered interest. HPV and HCMV coinfection has been reported to lead to a two-fold increase in lymph node metastasis in cervical

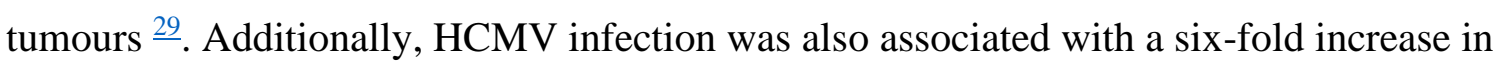
integrated forms of HPV16 in cervical lesions and contributed to the development of cervical cancer $\stackrel{30}{\underline{3}}$.

Apart from viruses, overexpression of certain molecular markers is also thought to contribute to GBM development and progression. The expression of Epidermal Growth Factor Receptor 
(EGFR), Cycloxygenase-2 (COX2), Cyclin D1 and p53 have been found to be elevated in GBM and have been correlated with clinical outcome and treatment response. The pathogenesis of GBM is not clearly understood despite much research and a viral infection is believed to be responsible for at least some GBM cases. The role of Human Cytomegalovirus (HCMV) in GBM formation is most convincing among all viruses, but unanimous evidence for its use as a therapeutic agent and possible oncogenic factor is missing. Since HPV has high incidence in our population and is thought to play a part in various cancers, we aim to study its presence in GBM patients as well and any HCMV/HPV co-infection that may be present. 


\section{MATERIALS AND METHODS}

This study was a retrospective series. A total of 112 patients who had been diagnosed with and treated for GBM at Aga Khan University Hospital (AKUH) in the years 2015-2016 were recruited. The study was given ethical approval by the Ethical Review Committee of AKUH (ERC number: 4197-Sur-ERC-17). Written informed consent for participation was taken prior to the study and patient information and follow up data was collected using medical records and patient follow up visits. Formalin-fixed paraffin-embedded biopsies were used to extract genomic DNA by QIAamp DNA Mini Kit (QIAGEN GmbH, Hilden Germany) according to the manufacturer's protocol. $25 \mu \mathrm{L}$ PCR reaction mixtures for CMV, HPV and $\beta$-globin were prepared using (GoTaq ${ }^{\circledR}$ Green Master Mix) according to manufacturer's protocol. All primers sequences used are outlined in Table 1.

\section{$\underline{\text { CMV detection }}$}

Nested PCR was performed using external and internal oligonucleotide primers specific for CMV glycoprotein B gene $\stackrel{31}{2}$ and PC03/PC04 for $\beta$-globin. The PCR thermal profile started with initial denaturation for $15 \mathrm{~min}$ at $95^{\circ} \mathrm{C}$. Then 45 amplification cycles were performed as follows: denaturing at $94^{\circ} \mathrm{C}$ for $30 \mathrm{~s}$, annealing for $30 \mathrm{~s}$ at $56^{\circ} \mathrm{C}$, and extension at $72^{\circ} \mathrm{C}$ for $40 \mathrm{~s}$. A final extension at $72^{\circ} \mathrm{C}$ for 10 min completed the PCR amplification. For $\beta$-globin, the PCR thermal profile was $94^{\circ} \mathrm{C}$ for $5 \mathrm{~min}$, followed by 40 cycles of $94^{\circ} \mathrm{C}$ for $30 \mathrm{~s}, 51^{\circ} \mathrm{C}$ for $30 \mathrm{~s}, 72^{\circ} \mathrm{C}$ for $30 \mathrm{~s}$, and $5 \mathrm{~min}$ final extension at $72^{\circ} \mathrm{C}$.

\section{$\underline{\text { HPV detection }}$}

Samples were analyzed for HPV by PCR using four sets of primers, i.e., GP5/GP6, general primers for HPV; TS16-A/TS16-B and TS18-A/TS-18B as subtype-specific primers for HPV

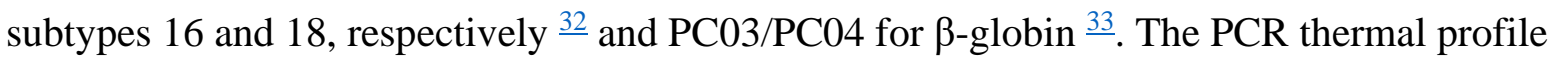


was as follows: $95^{\circ} \mathrm{C}$ for $5 \mathrm{~min}$, then 40 cycles of $94^{\circ} \mathrm{C}$ for $30 \mathrm{~s}, 45^{\circ} \mathrm{C}$ for $30 \mathrm{~s}, 72^{\circ} \mathrm{C}$ for $30 \mathrm{~s}$, and final extension of $5 \mathrm{~min}$ at $72^{\circ} \mathrm{C}$. PCR conditions for HPV 16 and 18 were the same as those for general primers (GP), except that the annealing temperatures were $58^{\circ} \mathrm{C}$ and $60^{\circ} \mathrm{C}$, respectively. For $\beta$-globin, the thermal profile is mentioned above.

PCR products were separated on agarose gel (2\%) premixed with $0.5 \mu \mathrm{g} / \mathrm{ml}$ ethidium bromide. The size of the resolved products was determined either with 100bp Plus DNA ladder. Agarose gel was run at $120 \mathrm{~V}$ for 15 minutes, observed under UV light and photographed.

Samples that resulted positive for HPV were confirmed by sequencing. Amplified PCR products of general and type-specific HPV16 and HPV18 were sent to Macrogen South Korea, Inc. (http://www.macrogen.com/ko/main/index.php) for gene sequencing. The sequenced data was then analysed using BLAST (Basic Local Alignment Search Tool) available online at the website of National Centre for Biotechnology Information.

\section{$\underline{\text { Molecular markers expression }}$}

Samples that resulted positive for HPV were further analyzed using immunohistochemistry (IHC) for the status of EGFR, COX2, Cyclin D1 and p53. All staining was performed using primary antibodies from Dako, Denmark, according to manufacturer's recommendations, previously optimized protocols and scoring criteria $\underline{34, \underline{35}}$.

\section{$\underline{\text { Statistical methods }}$}

Analysis was performed using SPSS version 22. Descriptive analysis were performed, for continuous variables Mean \pm S.D or Median (IQR) was reported depending on the normality assumption of the variables and assessed for the 2 groups (i.e. HPV positive and HPV 
negative) by independent $\mathrm{t}$ test or Wilcoxon rank sum (Mann Whitney test) respectively. For Categorical variables frequency with percentages was reported and was assessed for the 2 groups by chi-square test of independence if frequency in each cell is $\geq 5$ and if frequency was less than 5 in any cell fisher's exact test was used.

Follow-up time for each patient was calculated in months. The overall survival time was measured from the date of surgery to the date of death (treatment failure) or, if the patient was alive, then until the date of last follow-up. Patients who were alive at the time of last contact were considered as censored observation in overall survival analysis. Kaplan-Meier survival curves, log-rank tests and Cox proportional hazards regression analysis were used to compare overall survival (death). A second proportional hazard regression model adjusted for the other covariates of the study was used to examine the independent effect of treatment. Adjusted Hazard Ratio (aHR) with their 95\% CI was reported. A p-value of $<0.05$ was considered as significant. 


\section{RESULTS}

There were a total of 112 patients in our study comprising of $76(68 \%)$ males and $36(32 \%)$ females. Patients ranged from 6 - 81 years of age with the mean age of our study population being 47.83 years $(S D \pm 15.85)$. The type of brain tumour in all patients was a glioblastoma (WHO astrocytoma Grade IV).

HCMV was positive in a single patient, who was a 61 year old female and tested negative for HPV status. For HPV detection, general primers were used which resulted positive in 31 (28\%) patients. Out of these 31 positive specimens, 18 (16\%) were detected as HPV16 positive, $22(20 \%)$ were HPV18 and 2 specimens were not type 16 or 18 and were classified as HPV others (Figure 1). Co-infection of HPV16 and HPV18 was seen in 11 out of 31 cases. For confirmation of HPV presence, positive PCR products for HPV general and type specific 16 and 18 were confirmed through sequencing. There was $99 \%$ compatibility between our PCR and gene sequencing results. A total of 11 patients exhibited co-infection of HPV16 and HPV18 both. Any correlations between HPV positivity and patient clinicopathological factors were tested using Chi-square or Fishers' exact test, wherever necessary. There was no significant association between any patient factor and HPV status as listed in Table 2.

The status of molecular markers EGFR, COX2, Cyclin D1 and p53 was tested using IHC on the HPV positive specimens $(n=31)$. Each case of HPV positive GBM overexpressed at least one of the molecular markers tested, with COX2 being the most frequent $(n=20 / 31)$, followed by Cyclin D1 $(n=19 / 31)$, p53 $(n=15 / 31)$ and EGFR $(n=14 / 31)$. Co-expression of EGFR, Cyclin D1 and COX2 all together was also regularly observed (16\%), but none of the molecular markers were correlated with one another, as established using the Phi test $(\mathrm{p}=$ $>0.05)$. Furthermore, H\&E slides of all cases were reviewed by two independent histopathologists to identify any differentiating features based on HPV infection. However, no remarkable differences in microscopic features were observed. Typical microscopic 
features of GBM such as presence of necrotic areas, "chicken-wire" network of blood vessels, pleomorphic cells with elongated hyperchromatic nuclei, eosinophilic cytoplasm and endothelial proliferation were observed. All cases were positive for GFAP and an overwhelming majority had increased ki-67 expression, though to varying degrees. To study the effect of HPV infection on overall survival of glioblastoma patients, KaplanMeier survival curves, log-rank tests and Cox proportional hazards regression analysis were performed. Complete survival data was available for 60 out of 112 patients. The overall mean survival time for the study participants was 10.3 months, while the survival time of the CMV+ patient was 16 months. Figure 2 shows the Kaplan-Meier curves for HPV+ and HPVpatients. It was observed that HPV positive patients had longer survival times (13 months) in comparison to HPV negatives ones (9 months). However, this did not translate to statistical significance (Table 3). Moreover, age was significantly correlated with overall survival as with every one year increase in age the hazard of death was increased by $3 \%$. 


\section{DISCUSSION}

This study is the first to explore the role of infectious agents HCMV and HPV in glioblastoma patients of Pakistan. We found a high prevalence of HPV in our GBM population and a single case of HCMV infection. A novel finding of our study was the coinfection of HPV16 and 18 found in 11 out of 31 cases. Upon correlation with overall survival, it was found that HPV infection did not have any statistically valid effect on the prognosis of GBM patients, although HPV positive patients did have longer survival times than their negative counterparts. We further investigated any histological differences occurring due to HPV infection, but found no discerning features in the HPV positive cases. The expression of commonly used biomarkers EGFR, COX2, Cyclin D1 and p53 was assessed in HPV positive cases and at least one marker was overexpressed in all cases, with COX2 being the most common. The trio of EGFR, COX2 and Cyclin D1 was overexpressed together in $16 \%$ cases, although no correlations among any of the markers could be established statistically.

There are certain features typical to the majority of GBM cases. These include the male sex, age close to 45 years, white race, prior exposure to ionizing radiation and certain underlying genetic disorders such as tuberous sclerosis, neurofibromatosis type $1 \& 2$, Turcot syndrome and Li-Fraumeni syndrome ${ }^{2}$. These findings are consistent with our cohort, as there were $76 \%$ males as compared to $36 \%$ females and the mean age was 47 years. Similar figures were reported by Ahsan et $\mathrm{al}^{\frac{36}{6}}$. who performed a single-centre study showing that the mean age was 47 years in Pakistan as compared to the 64 years on presentation in the US ${ }^{1}$.

Viral infections have been linked to the development of a spectrum of clinical disorders including cancer. In the Pakistani population, the seroprevalence of HCMV was found to be very high at $93.2 \%$ for $\operatorname{IgG}$ and $4.3 \%$ for $\operatorname{IgM}$ respectively ${ }^{37}$. Other local studies have found 
HCMV infection to be responsible for congenital defects among neonates and $6 \%$ of Pakistani women of childbearing age are at risk of primary infection ${ }^{38,39}$.

Over a decade has passed since the discovery of HCMV in a few GBM samples by Cobbs et

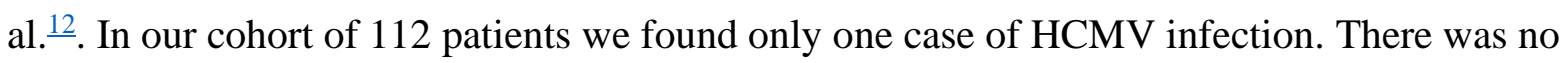
correlation of HCMV positivity with any of the clinicopatholgical factors tested. Another study by Lau et al. also reported complete absence of HCMV in various carcinomas and sarcomas using immunohistochemistry, in situ hybridization and $\mathrm{PCR}^{\underline{13}}$. Since the results of Cobbs et al. have not been reproduced satisfactorily, the association of HCMV with GBM is still not established. It is hypothesized that HCMV may give rise to gliomagenesis, enhance tumourigenesis or reactivate itself in tumour formation and the latest consensus is that the role of HCMV cannot be ignored ${ }^{7}$. The results of HCMV may not be sufficient to show a direct association with GBM, however, the possibility of a link cannot be completely ruled out for the population of Pakistan. As suggested by previous researches conducted in Japan where HCMV was not detected, geographical variation may be a possible explanation for this outcome $^{18}$. Various studies have concurred that the presence and role of HCMV in GBM cannot be excluded at the very least ${ }^{?}$.

The Pakistani population also suffers from high HPV incidence. A study by Bruni at al. in 2012 found that $88 \%$ of all cases of cervical carcinoma were due to HPV infection, while the

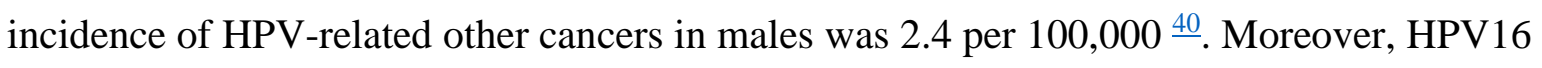
was found to be significantly associated with cervical cancer in Pakistani women and oral squamous cell carcinoma in Pakistani men ${ }^{41}, \underline{42}$.

$\mathrm{HPV}$, in its limited research with brain tumor tissue, has emerged as a virus consistent in its outcomes with all three studies, including ours. Vidone et al. established the existence of HPV in GBM specimens from the eastern European population where $23 \%$ of samples tested positive, in which $25 \%$ showed HPV16 dominance associated with poor prognosis $\frac{28}{\text {. The }}$ 
first study done on the Asian population to check for the presence of eight known oncogenic viruses showed $21 \%$ of samples to be HPV positive while no other viruses were detected ${ }^{18}$. Our results show presence of HPV in $28 \%$ of GBM patients, out of which the majority were infected with HPV18. We also found positivity of HPV16 and 18 both in 11 cases which was a finding unique to our cohort. Existing literature on Pakistani patients shows us that HPV16 was more prevalent than type 18 for oral and cervical cancer both ${ }^{41,42}$. Moreover, in our

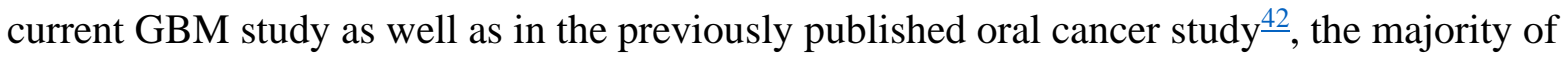
HPV positive patients were male. This begs further investigation into how males are more susceptible or more exposed to HPV infections in oral as well as brain cancers.

As mentioned earlier, the E6 and E7 core genes of HPV can cause the dysregulation of various processes responsible for oncogenic transformation in the $\mathrm{CNS}^{27}$. Moreover, heparin sulfate proteoglycans (HSPG) have been found to be the primary binding sites for HPV virions which are an element of the cellular components of the brain, as also suggested by Vidone et al. $28,43,44$.

The overexpression of molecular markers observed in HPV positive cases corresponds with present literature. EGFR is found overexpressed in $60 \%$ of primary glioblastomas $\frac{45}{}$, COX2 in $75 \%$ of glioblastoma ${ }^{46}$, Cyclin D1 in $31 \%$ of low grade and $62 \%$ of high grade gliomas $\frac{47}{}$ and p53 in $42 \%$ of low-grade and $64 \%$ of high grade gliomas ${ }^{48}$. However, we did not find any literature regarding the association of HPV and EGFR, COX2, Cyclin D1 and p53 in GBM. Nevertheless, we did find overexpression of at least one biomarker in all HPV positive cases and COX2 overexpression was the most common at $65 \%$.

Our findings make a strong case for further investigation into the role of viruses in gliomagenesis and the molecular basis for this neoplasia. If HPV is a causative factor for GBM then preventive measures may be applied as is the case with HPV-induced cervical cancer patients which may prolong patient survival. 


\section{CONCLUSIONS}

Our findings make a strong case for further investigation into the role of viruses in gliomagenesis and the molecular basis for this neoplasia. Since CMV was very scarce in our study we propose other factors may be influencing the development of gliomas in the Pakistani population. If HPV is a causative factor for GBM, which needs further investigation, then preventive measures may be applied as is the case with HPV-induced cervical cancer patients which may prolong patient survival. 


\section{FUNDING SOURCE}

This work was supported by funds of the Departmental of Surgery, Aga Khan University awarded to Dr S. M. Adnan Ali. 


\section{DECLARATION OF INTEREST}

Declarations of interest: none. 


\section{AUTHOR CONTRIBUTIONS}

AA: PI of grant which supported the bench work of this project, writing study proposal, supervision of bench work, procuring approval from ethical committee YM: Manuscript preparation, review and final editing and bench work of PCR and IHC ZA: Review of H\&E and IHC slides NZ: Performed data entry, statistical analysis and reporting.

SAE: Providing access to patients and specimens, medical history and follow up data and overall supervision of research project. 


\section{REFERENCES}

1. Ostrom QT, Gittleman H, Xu J, Kromer C, Wolinsky Y, Kruchko C, et al. CBTRUS Statistical Report: Primary Brain and Other Central Nervous System Tumors Diagnosed in the United States in 2009-2013. Neuro Oncol. 2016;18(suppl_5):v1-v75.

2. Anjum K, Shagufta BI, Abbas SQ, Patel S, Khan I, Shah SAA, et al. Current status and future therapeutic perspectives of glioblastoma multiforme (GBM) therapy: A review. Biomed Pharmacother. 2017;92:681-689.

3. Ray S, Bonafede MM, Mohile NA. Treatment Patterns, Survival, and Healthcare Costs of Patients with Malignant Gliomas in a Large US Commercially Insured Population. Am Health Drug Benefits. 2014;7(3):140-149.

4. Ahsan J, Hashmi SN, Muhammad I, Din HU, Butt AM, Nazir S, et al. Spectrum of central nervous system tumours-a single center histopathological review of 761 cases over 5 years. Journal of Ayub Medical College Abbottabad. 2015;27(1):81-84.

5. Stupp R, Mason WP, van den Bent MJ, Weller M, Fisher B, Taphoorn MJ, et al. Radiotherapy plus concomitant and adjuvant temozolomide for glioblastoma. $N$ Engl J Med. 2005;352(10):987-996.

6. Thakkar JP, Dolecek TA, Horbinski C, Ostrom QT, Lightner DD, Barnholtz-Sloan JS, et al. Epidemiologic and molecular prognostic review of glioblastoma. Cancer Epidemiology and Prevention Biomarkers. 2014;23(10):1985-1996.

7. Dziurzynski K, Chang SM, Heimberger AB, Kalejta RF, McGregor Dallas SR, Smit M, et al. Consensus on the role of human cytomegalovirus in glioblastoma. Neuro Oncol. 2012;14(3):246-255.

8. Varnum SM, Streblow DN, Monroe ME, Smith P, Auberry KJ, Pasa-Tolic L, et al. Identification of proteins in human cytomegalovirus (HCMV) particles: the HCMV proteome. J Virol. 2004;78(20):10960-10966.

9. Reeves $M$, Sinclair J. Aspects of human cytomegalovirus latency and reactivation. Curr Top Microbiol Immunol. 2008;325:297-313.

10. Michaelis M, Doerr HW, Cinatl J. The story of human cytomegalovirus and cancer: increasing evidence and open questions. Neoplasia. 2009;11(1):1-9.

11. Herbein $\mathrm{G}$, Kumar A. The oncogenic potential of human cytomegalovirus and breast cancer. Front Oncol. 2014;4:230.

12. Cobbs CS, Harkins L, Samanta M, Gillespie GY, Bharara S, King PH, et al. Human cytomegalovirus infection and expression in human malignant glioma. Cancer Res. 2002;62(12):3347-3350.

13. Lau SK, Chen YY, Chen WG, Diamond DJ, Mamelak AN, Zaia JA, et al. Lack of association of cytomegalovirus with human brain tumors. Mod Pathol. 2005;18(6):838-843.

14. Lucas KG, Bao L, Bruggeman R, Dunham K, Specht C. The detection of CMV pp65 and IE1 in glioblastoma multiforme. J Neurooncol. 2011;103(2):231-238.

15. Ranganathan P, Clark PA, Kuo JS, Salamat MS, Kalejta RF. Significant association of multiple human cytomegalovirus genomic Loci with glioblastoma multiforme samples. J Virol. 2012;86(2):854-864.

16. Wick W, Platten M. CMV infection and glioma, a highly controversial concept struggling in the clinical arena. Neuro Oncol. 2014;16(3):332-333. 
17. Yamashita $\mathrm{Y}$, Ito $\mathrm{Y}$, Isomura $\mathrm{H}$, Takemura N, Okamoto A, Motomura K, et al. Lack of presence of the human cytomegalovirus in human glioblastoma. Mod Pathol. 2014;27(7):922-929.

18. Hashida Y, Taniguchi A, Yawata T, Hosokawa S, Murakami M, Hiroi M, et al. Prevalence of human cytomegalovirus, polyomaviruses, and oncogenic viruses in glioblastoma among Japanese subjects. Infect Agent Cancer. 2015;10:3.

19. Harden ME, Munger K. Human papillomavirus molecular biology. Mutat Res. 2017;772:3-12.

20. Gillison ML, Chaturvedi AK, Lowy DR. HPV prophylactic vaccines and the potential prevention of noncervical cancers in both men and women. Cancer. 2008;113(10 Suppl):3036-3046.

21. Chaturvedi AK, Engels EA, Pfeiffer RM, Hernandez BY, Xiao W, Kim E, et al. Human papillomavirus and rising oropharyngeal cancer incidence in the United States. $J$ Clin Oncol. 2011;29(32):4294-4301.

22. Herrero R, Castellsague X, Pawlita M, Lissowska J, Kee F, Balaram P, et al. Human papillomavirus and oral cancer: the International Agency for Research on Cancer multicenter study. J Natl Cancer Inst. 2003;95(23):1772-1783.

23. Tota JE, Chevarie-Davis M, Richardson LA, Devries M, Franco EL. Epidemiology and burden of HPV infection and related diseases: implications for prevention strategies. Prev Med. 2011;53 Suppl 1:S12-21.

24. Klingelhutz AJ, Roman A. Cellular transformation by human papillomaviruses: lessons learned by comparing high- and low-risk viruses. Virology. 2012;424(2):77-98.

25. Nobre RJ, Herraez-Hernandez E, Fei JW, Langbein L, Kaden S, Grone HJ, et al. E7 oncoprotein of novel human papillomavirus type 108 lacking the E6 gene induces dysplasia in organotypic keratinocyte cultures. J Virol. 2009;83(7):2907-2916.

26. Doorbar J. Molecular biology of human papillomavirus infection and cervical cancer. Clin Sci (Lond). 2006;110(5):525-541.

27. Piltti K, Kerosuo L, Hakanen J, Eriksson M, Angers-Loustau A, Leppa S, et al. E6/E7 oncogenes increase and tumor suppressors decrease the proportion of self-renewing neural progenitor cells. Oncogene. 2006;25(35):4880-4889.

28. Vidone M, Alessandrini F, Marucci G, Farnedi A, de Biase D, Ricceri F, et al. Evidence of association of human papillomavirus with prognosis worsening in glioblastoma multiforme. Neuro Oncol. 2014;16(2):298-302.

29. Chen T-M, Chen Y-H, Wu C-C, Chen C-A, Chang C-F, Hsieh C-Y. Factors influencing tumor cell kinetics in cervical cancer. J Cancer Res Clin Oncol. 1996;122(8):504-508.

30. Szostek S, Zawilinska B, Kopec J, Kosz-Vnenchak M. Herpesviruses as possible cofactors in HPV-16-related oncogenesis. Acta Biochim Pol. 2009;56(2):337.

31. Kuhn JE, Wendland T, Eggers HJ, Lorentzen E, Wieland U, Eing B, et al. Quantitation of human cytomegalovirus genomes in the brain of AIDS patients. J Med Virol. 1995;47(1):70-82.

32. Baay MF, Quint WG, Koudstaal J, Hollema H, Duk JM, Burger MP, et al. Comprehensive study of several general and type-specific primer pairs for detection of human papillomavirus DNA by PCR in paraffin-embedded cervical carcinomas. $J$ Clin Microbiol. 1996;34(3):745-747.

33. Mikaelsdottir EK, Benediktsdottir KR, Olafsdottir K, Arnadottir T, Ragnarsson GB, Olafsson $\mathrm{K}$, et al. HPV subtypes and immunological parameters of cervical cancer in 
Iceland during two time periods, 1958-1960 and 1995-1996. Gynecol Oncol. 2003;89(1):22-30.

34. Mirza Y, Ali SMA, Awan MS, Idress R, Naeem S, Zahid N, et al. Overexpression of EGFR in Oral Premalignant Lesions and OSCC and Its Impact on Survival and Recurrence. Oncomedicine. 2018;3:28-36.

35. Ali S, Awan MS, Ghaffar S, Azam S, Pervez S. TP53 protein overexpression in oral squamous cell carcinomas (OSCC): correlation with histologic variables and survival outcome in Pakistani patients. Oral Surgery. 2010;3(3):83-95.

36. Ahsan J, Hashmi SN, Muhammad I, Din HU, Butt AM, Nazir S, et al. Spectrum of Central Nervous System Tumours--a Single Center Histopathological Review of 761 Cases over 5 Years. J Ayub Med Coll Abbottabad. 2015;27(1):81-84.

37. Ibrahim S, Siddiqui AA, Siddiqui AR, Ahmed W, Moss PA, Lalani EM.

Sociodemographic factors associated with IgG and IgM seroprevalence for human cytomegalovirus infection in adult populations of Pakistan: a seroprevalence survey. BMC Public Health. 2016;16(1):1112.

38. Mujtaba G, Shaukat S, Angez M, Alam MM, Hasan F, Zahoor Zaidi SS, et al. Seroprevalence of Human Cytomegalovirus (HCMV) infection in pregnant women and outcomes of pregnancies with active infection. J Pak Med Assoc. 2016;66(8):1009-1014.

39. Siddiqui AR, Ibrahim S, Siddiqui AA, Moss P, Lalani EN. Human Cytomegalovirus: a neglected public health area of significant relevance to women, the foetus and new born. Time for action! J Pak Med Assoc. 2017;67(6):827-829.

40. Bruni L B-RL, Albero G, Serrano B, Mena M, Gómez D, Muñoz J, Bosch FX, de Sanjosé, S. Human Papillomavirus and Related Diseases in Pakistan. ICO Information Centre on HPV and Cancer (HPV Information Centre). 2017.

41. Khan S, Jaffer NN, Khan MN, Rai MA, Shafiq M, Ali A, et al. Human papillomavirus subtype 16 is common in Pakistani women with cervical carcinoma. Int J Infect Dis. 2007;11(4):313-317.

42. Ali SMA, Awan MS, Ghaffar S, Salahuddin I, Khan S, Mehraj V, et al. Human papillomavirus infection in oral squamous cell carcinomas: correlation with histologic variables and survival outcome in a high risk population. Oral Surgery. 2008;1(2):96105.

43. Properzi F, Lin R, Kwok J, Naidu M, van Kuppevelt TH, Ten Dam GB, et al. Heparan sulphate proteoglycans in glia and in the normal and injured CNS: expression of sulphotransferases and changes in sulphation. Eur J Neurosci. 2008;27(3):593-604.

44. Surviladze Z, Dziduszko A, Ozbun MA. Essential roles for soluble virion-associated heparan sulfonated proteoglycans and growth factors in human papillomavirus infections. PLoS Pathog. 2012;8(2):e1002519.

45. Xu H, Zong H, Ma C, Ming X, Shang M, Li K, et al. Epidermal growth factor receptor in glioblastoma. Oncol Lett. 2017;14(1):512-516.

46. Prayson RA, Castilla EA, Vogelbaum MA, Barnett GH. Cyclooxygenase-2 (COX-2) expression by immunohistochemistry in glioblastoma multiforme. Ann Diagn Pathol. 2002;6(3):148-153.

47. Tan P, Xing Z, Li Z. Expression of cyclin D1 in brain gliomas and its significance. $A i$ zheng $=$ Aizheng $=$ Chinese journal of cancer. 2004;23(1):63-65.

48. Jin $Y$, Xiao W, Song T, Feng G, Dai Z. Expression and prognostic significance of p53 in glioma patients: a meta-analysis. Neurochem Res. 2016;41(7):1723-1731. 
Ali. 21 


\section{FIGURE CAPTIONS}

Figure 1: Kaplan Meier survival curves in 60 GBM patients selected according to (A) CMV status, (B) HPV status, (C) HPV16 status and (D) HPV18 status

Figure 2 (A): PCR amplification of HPV general, HPV type 16 and HPV type 18 in GBM samples. Products were electrophoresed on $2 \%$ agarose gel and stained with ethidium bromide. From left to right: sample 117 is HPV-, 118 and 119 are HPV+ with positive control marked, DNA ladder of 100bp, positive control of HPV18, sample 4 HPV18+, positive control of HPV16 and sample 4 HPV16+. It is to be noted that sample 4 has coinfection of HPV16 and HPV18

Figure 2 (B): PCR amplification of HCMV in GBM samples. Products were electrophoresed on $2 \%$ agarose gel and stained with ethidium bromide. From left to right: DNA ladder of 100bp, negative control, positive control of CMV, samples 3, 5, 6 and 7 are CMV- and sample 4 is $\mathrm{CMV}+$.

\section{TABLES}

Table 1 Primers used for PCR

\begin{tabular}{|c|c|c|c|c|}
\hline & Primer & Sequence & $\begin{array}{c}\text { Target } \\
\text { gene }\end{array}$ & $\begin{array}{c}\text { Amplimer } \\
\text { length }\end{array}$ \\
\hline \multirow{2}{*}{$\begin{array}{l}\text { HPV } \\
\text { General }\end{array}$} & GP5 & TTTGTTACTGTGGTAGATACTAC & \multirow[t]{2}{*}{ L1 } & \multirow[t]{2}{*}{$155 \mathrm{bp}$} \\
\hline & GP6 & GAAAAATAAACTGTAAATCATATTC & & \\
\hline \multirow{2}{*}{$\begin{array}{l}\text { HPV } \\
\text { type16 }\end{array}$} & TS16-A & GGTCGGTGGACCGGTCGATG & \multirow[t]{2}{*}{ L1 } & \multirow[t]{2}{*}{$96 \mathrm{bp}$} \\
\hline & TS16-B & GCAATGTAGGTGTATCTCCA & & \\
\hline \multirow{2}{*}{$\begin{array}{l}\text { HPV } \\
\text { type } 18\end{array}$} & TS18-A & CCTTGGACGTAAATTTTTGG & \multirow[t]{2}{*}{ L1 } & \multirow[t]{2}{*}{115 bp } \\
\hline & TS18-B & CACGCACACGCTTGGCAGGT & & \\
\hline$\beta$-globin & PC03 & ACACAACTGTGTTCACTAGC & $\beta$-Globin & $110 \mathrm{bp}$ \\
\hline
\end{tabular}




\begin{tabular}{|l|l|l|c|c|}
\hline & PC04 & CAACTTCATCCACGTTCACC & & \\
\hline CMV & CMVXF & TCCAACACCCACAGTACCCGT & glycoprotein & $267 \mathrm{bp}$ \\
\cline { 2 - 3 } & CMVXR & CGGAAACGATGGTGTAGTTCG & B & \\
\cline { 2 - 3 } & CMVIF & TGACGGTCAAGGATCAGTGGC & & $146 \mathrm{bp}$ \\
\cline { 2 - 3 } & CMVIF & GTAAACCACATCACCCGTGGA & & \\
\hline
\end{tabular}

Table 2 Correlation of HPV status with patient characteristics $(n=112)$

\begin{tabular}{|c|c|c|c|c|c|c|c|c|}
\hline & & \multirow{2}{*}{\multicolumn{2}{|c|}{ Total }} & \multicolumn{4}{|c|}{ HPV Status } & \multirow{3}{*}{$P$ value } \\
\hline \multirow{2}{*}{\multicolumn{2}{|c|}{ Factors }} & & & \multicolumn{2}{|c|}{$\begin{array}{c}\text { Positive } \\
(n=31)\end{array}$} & \multicolumn{2}{|c|}{$\begin{array}{c}\text { Negative } \\
(n=81)\end{array}$} & \\
\hline & & $\mathbf{N}$ & $\%$ & $\mathbf{N}$ & $\%$ & $\mathbf{N}$ & $\%$ & \\
\hline \multirow[t]{2}{*}{ Gender } & Male & 76 & 68 & 23 & 74 & 53 & 65 & \multirow[t]{2}{*}{0.374} \\
\hline & Female & 36 & 32 & 8 & 26 & 28 & 35 & \\
\hline \multirow{10}{*}{$\begin{array}{l}\text { Site of } \\
\text { Lesion }\end{array}$} & Brain & 27 & 24 & 4 & 13 & 23 & 28 & \multirow[t]{10}{*}{0.195} \\
\hline & Frontal & 13 & 12 & 2 & 7 & 11 & 14 & \\
\hline & Parietal & 16 & 14 & 7 & 23 & 9 & 11 & \\
\hline & Temporal & 28 & 25 & 8 & 26 & 20 & 25 & \\
\hline & Occipital & 2 & 2 & 1 & 3 & 1 & 1 & \\
\hline & $\begin{array}{l}\text { Fronto- } \\
\text { Parietal } \\
\end{array}$ & 8 & 7 & 3 & 10 & 5 & 6 & \\
\hline & $\begin{array}{l}\text { Fronto- } \\
\text { temporal }\end{array}$ & 3 & 3 & 0 & 0 & 3 & 4 & \\
\hline & $\begin{array}{l}\text { Temporo- } \\
\text { parietal }\end{array}$ & 7 & 6 & 2 & 7 & 5 & 6 & \\
\hline & $\begin{array}{l}\text { Parieto- } \\
\text { Occipital }\end{array}$ & 4 & 4 & 3 & 4 & 3 & 4 & \\
\hline & Others & 4 & 4 & 3 & 10 & 1 & 1 & \\
\hline \multirow{3}{*}{$\begin{array}{l}\text { Living } \\
\text { Status }\end{array}$} & Alive & 17 & 15 & 6 & 19 & 11 & 14 & \multirow[t]{3}{*}{0.233} \\
\hline & Dead & 43 & 39 & 8 & 26 & 35 & 43 & \\
\hline & LFUP & 52 & 46 & 17 & 55 & 35 & 43 & \\
\hline \multirow[t]{2}{*}{ HCMV } & Positive & 1 & 1 & 0 & 0 & 1 & 1 & \multirow[t]{2}{*}{$>0.99$} \\
\hline & Negative & 111 & 99 & 31 & 100 & 80 & 99 & \\
\hline
\end{tabular}

p-value considered significant at $<0.05$ 
Table 3 Correlation of clinicopathologic factors with HPV status of GBM patients ( $n=60)$

\begin{tabular}{|c|c|c|c|c|c|c|c|}
\hline \multicolumn{8}{|c|}{ UNIVARIATE ANALYSIS } \\
\hline \multirow{3}{*}{ Factor } & \multirow{3}{*}{ Group } & \multicolumn{6}{|c|}{$\begin{array}{l}\text { Overall survival } \\
\end{array}$} \\
\hline & & \multirow[t]{2}{*}{$\mathbf{N}$} & \multirow[t]{2}{*}{ Months } & \multirow[t]{2}{*}{ P-value } & \multirow{2}{*}{$\begin{array}{c}\text { Hazard } \\
\text { ratios }\end{array}$} & \multicolumn{2}{|c|}{$\begin{array}{c}95 \% \text { Confidence } \\
\text { interval }\end{array}$} \\
\hline & & & & & & Lower & Upper \\
\hline Age & - & 112 & - & $0.008^{*}$ & 1.029 & 1.008 & 1.052 \\
\hline \multirow[t]{2}{*}{ Gender } & Male & 76 & 10 & \multirow[t]{2}{*}{.970} & 0.987 & 0.498 & 1.957 \\
\hline & Female & 36 & 10 & & 1 & & \\
\hline \multirow{9}{*}{$\begin{array}{l}\text { Site of } \\
\text { Lesion }\end{array}$} & Brain & 27 & 10 & \multirow[t]{9}{*}{0.757} & 0.885 & 0.396 & 1.979 \\
\hline & Frontal & 13 & 9 & & 0.837 & 0.315 & 2.220 \\
\hline & Parietal & 16 & 4 & & 1.838 & 0.587 & 5.753 \\
\hline & Temporal & 28 & 9 & & 1 & & \\
\hline & Occipital & 2 & 14 & & 0.395 & 0.051 & 3.031 \\
\hline & $\begin{array}{l}\text { Fronto- } \\
\text { Parietal }\end{array}$ & 8 & 7 & & 1.050 & 0.236 & 4.681 \\
\hline & $\begin{array}{l}\text { Fronto- } \\
\text { temporal }\end{array}$ & 3 & 5 & & 1.753 & 0.225 & 13.692 \\
\hline & $\begin{array}{l}\text { Temporo- } \\
\text { parietal }\end{array}$ & 7 & 15 & & 0.277 & 0.036 & 2.125 \\
\hline & $\begin{array}{l}\text { Parieto- } \\
\text { Occipital }\end{array}$ & 4 & 12 & & 0.450 & 0.058 & 3.463 \\
\hline \multirow[t]{2}{*}{ HPV } & Positive & 31 & 13 & \multirow[t]{2}{*}{0.399} & 0.715 & 0.328 & 1.560 \\
\hline & Negative & 81 & 9 & & 1 & & \\
\hline \multirow[t]{2}{*}{ HPV16 } & Positive & 18 & 13 & \multirow[t]{2}{*}{0.537} & 0.744 & 0.291 & 1.901 \\
\hline & Negative & 94 & 10 & & 1 & & \\
\hline \multirow[t]{2}{*}{ HPV18 } & Positive & 22 & 13 & \multirow[t]{2}{*}{0.498} & 0.753 & 0.332 & 1.711 \\
\hline & Negative & 90 & 10 & & 1 & & \\
\hline \multicolumn{8}{|c|}{ MULTIVARIATE ANALYSIS } \\
\hline \multirow{3}{*}{ Factor } & \multirow{3}{*}{ Group } & \multicolumn{3}{|c|}{ Overall survival } & & & \\
\hline & & \multicolumn{2}{|l|}{$\mathbf{N}$} & \multirow[t]{2}{*}{$\begin{array}{l}P \text { - } \\
\text { value }\end{array}$} & HR & \multicolumn{2}{|c|}{$\begin{array}{l}95 \% \text { Confidence } \\
\text { interval }\end{array}$} \\
\hline & & & & & & Lower & Upper \\
\hline Age & - & 112 & & $0.013 *$ & 1.029 & 1.006 & 1.052 \\
\hline \multirow[t]{2}{*}{ HPV } & Positive & 31 & & \multirow[t]{2}{*}{0.825} & \multirow[t]{2}{*}{0.913} & \multirow[t]{2}{*}{0.407} & \multirow[t]{2}{*}{2.047} \\
\hline & Negative & 81 & & & & & \\
\hline
\end{tabular}

*p-value considered significant at $<0.05$

Months for overall survival were calculated through Kalpan Meier Log Rank test 

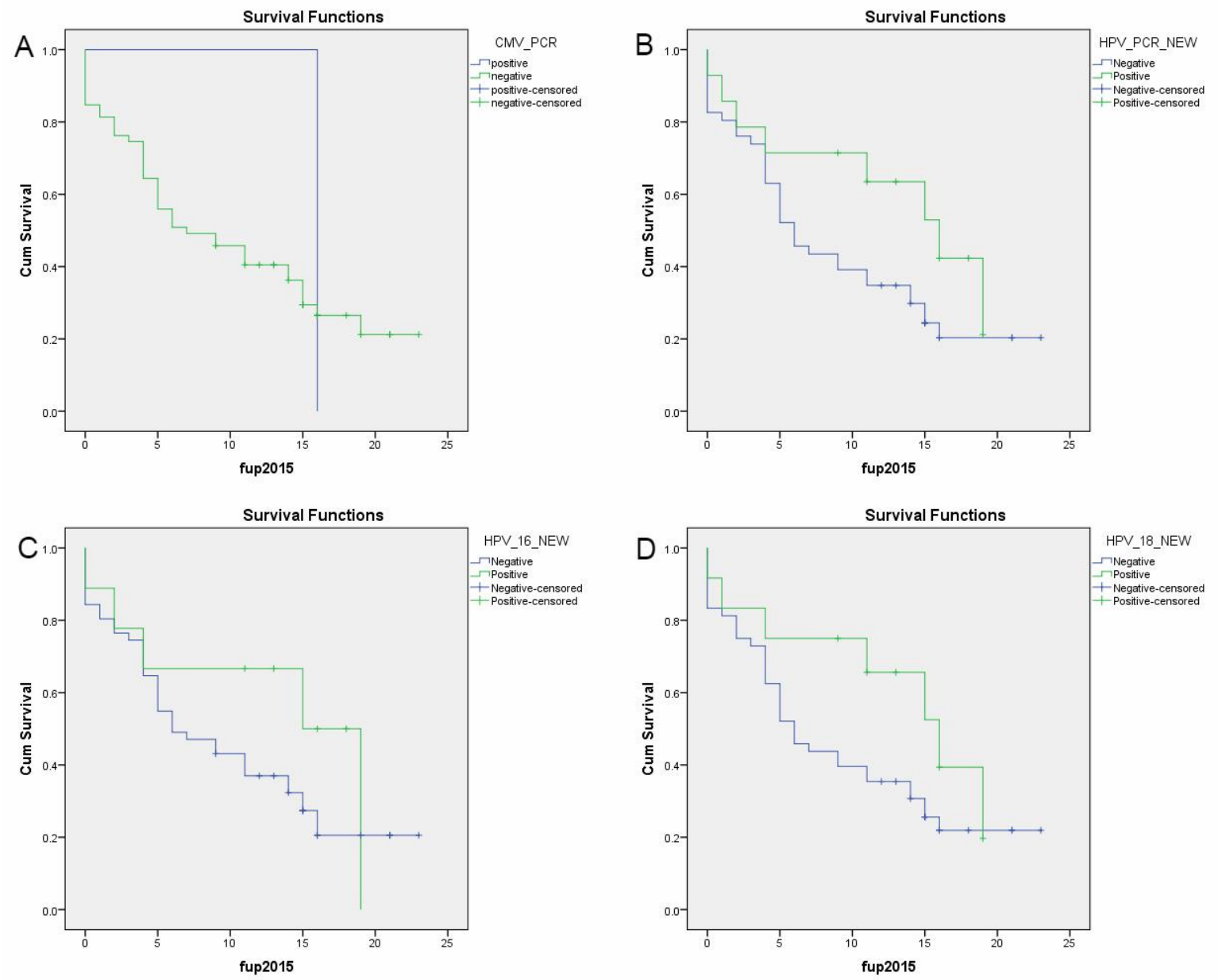

A

B

$\begin{array}{llllll}\text { Ladder NC PC } & 3 & 4 & 5 & 6 & 7\end{array}$ 117118119 PC Lad PC 0404 PC 0404 